\title{
Effect of storage conditions on the storage characteristics of macarons
}

\author{
Young Mi Park, Da Hee Kim, Su Jin Kim, Mee Ree Kim* \\ Department of Food and Nutrition, Chungnam National University, Daejeon 34134, Korea
}

\section{저장 조건에 따른 마카롱의 저장 특성}

\author{
박영미 · 김다희 · 김수진 · 김미리* \\ 충남대학교 식품영양학과
}

\begin{abstract}
The purpose of this study was to evaluate the storage characteristics of macarons following storage under a range of conditions. Thus, the macarons were stored under three different sets of conditions, namely refrigeration $\left(4^{\circ} \mathrm{C}\right)$, room temperature defrosting after freezing $\left(-20 \rightarrow 25^{\circ} \mathrm{C}\right)$, and refrigeration defrosting after freezing $\left(-20 \rightarrow 4^{\circ} \mathrm{C}\right)$, fillings were added during freezing. The volume, moisture content, and texture of each sample was determined, and sensory evaluations were conducted to identify the quality characteristics during storage. More specifically, in the case of the frozen samples, the volume was maintained at the beginning of the storage period, while in the refrigerated sample, the volume was maintained in the latter part of the storage period. In addition, the moisture content increased under all three conditions, and after three weeks, the highest moisture content was observed for the sample defrosted in the refrigerator after freezing. Examination of the textual properties (i.e., hardness, chewiness, and gumminess) showed increased values in the refrigerated sample, and reduced values in the frozen samples, whereby defrosting in the refrigerator gave the lowest value. In the sensory test, the overall acceptability was the highest for the sample defrosted at room temperature, resulting in the highest scores relating to color, nutty flavor, and nutty taste. Based on these results, it appears that when long-term storage is required, freezing in the presence of filling is considered optimal.
\end{abstract}

Key words : macaron, storage conditions, storage characteristics

\section{서 론}

디저트 시장은 매년 성장세를 보이는데, 그중에서도 마 카롱은 달콤한 맛뿐만 아니라, 모양과 색도 다양하여 소비 자들에게 많은 사랑을 받고 있다(aT, 2016; Park 등, 2018). 최근 젊은 층에서도 고혈압, 당뇨 등의 발병률이 증가하면 서 건강한 식습관, 건강에 대한 인식이 변화함에 따라 (Park과 Lee, 2016), 쿠키류 중 유일하게 밀가루가 첨가되 지 않는 마카롱은 그에 부합하는 디저트로써 소비자들의 관심이 더욱 큰 것으로 생각된다(Lee와 Kim, 2007; Lee
등, 2015). 마카롱은 아몬드 분말을 주재료로 달걀흰자, 슈가 파우더 등이 사용되어 고소하며, 부드러움과 부피감 을 갖는다(Kim 등, 2004). 아몬드는 혈당 조절과 콜레스테 롤 수치를 낮춰주는 것으로 보고되었는데(Lovejoy 등, 2002), 비타민 E가 풍부해 항산화 효과가 있고, 마그네슘 이 풍부해 뼈를 단단하게 하며, 그 외에도 플라보이드가 풍부해 심장질환에 도움을 준다(Beak 등, 2018). 아몬드 $100 \mathrm{~g}$ 기준 지질은 $49.96 \mathrm{~g}$ 인데, 불포화지방산이 $43.95 \mathrm{~g}$ 으 로 포화지방산에 비해 11 배 이상 많고, 단백질이 $23.44 \mathrm{~g}$, 식이섬유가 $14.5 \mathrm{~g}$ 으로 다양한 영양소와 생리활성을 나타

*Corresponding author. E-mail : mrkim@cnu.ac.kr, Phone : +82-42-821-6837, Fax : +82-42-821-8887

Received 10 February 2019; Revised 07 April 2020; Accepted 28 April 2020.

Copyright (c) The Korean Society of Food Preservation.

This is an Open Access article distributed under the terms of the Creative Commons Attribution Non-Commercial License (http://creativecommons.org/licenses/by-nc/4.0) which permits unrestricted non-commercial use, distribution, and reproduction in any medium, provided the original work is properly cited. 
낸다(NAAS, 2016). 또한, 달걀 흰자를 거품내어 만드는 머랭은 마카롱 반죽에 첨가되어 마카롱을 부풀게 하고, 결착능력을 가져 마카롱의 식감과 형태를 형성하도록 한 다(Korean Bakery Association, 2003).

현재까지 마카롱에 대한 연구는 난백분말 마카롱(Kim 과 $\mathrm{Sim}, 2017)$, 양배추 분말 마카롱(Kim, 2017), 백년초 분말 마카롱(Kim 등, 2017), 자일로스와 들깨 마카롱(Lee 등, 2015), 흑삼 마카롱(Bum, 2013) 등 기능성 식품을 첨가 한 마카롱의 품질 특성에만 한정되었고, 마카롱의 저장 안전성에 대한 연구는 이뤄지지 않은 실정이다. 마카롱은 구운 직후에는 머랭의 식감으로 인해 쫀득하지만(Kim 등, 2004), 시간이 지남에 따라 노화가 진행되어 수분의 증발 로 과자처럼 딱딱해진다(Won, 1999). 마카롱의 장기 보관 방법으로는 마카롱을 하루 동안 냉장 보관하여 숙성시킨 후, 냉동 보관하면 약 한 달간 보관이 가능하다고 알려져 있다(Seo, 2019). 그러나 저장 기간에 따라 제조 직후 마카 롱의 품질 특성을 어느 정도 유지했는지에 대한 실험 데이 터나 관련 연구는 전무한 실정이다. 따라서 본 논문에서는 냉장, 냉동 조건에서 저장하고 냉동저장한 마카롱은 실온 해동과 냉장 해동으로 해동하는 방법을 달리함으로써 마 카롱의 최적 저장방법을 찾고자 품질 특성을 측정하였다.

\section{재료 및 방법}

\section{실험재료}

본 실험에 사용된 마카롱 코크(coque)는 아몬드 분말 (G\&M Food System, Gyeongsan, Korea), 슈가파우더 (Serom Food, Icheon, Korea), 달걀(Happiness Egg, Daejeon, Korea), 설탕(CJ CheilJedang, Incheon, Korea)을 사용하여 제조하였다.

\section{시료 제조}

본 실험에서 마카롱 코크를 제조할 때 사용한 방법(Fig. 1)은 끓는 시럽을 이용한 이탈리안 머랭법이며, 배합비는 Table 1과 같다. 먼저 아몬드 분말과 슈가파우더 1:1 비율 에 달갈흰자를 섞어 아몬드 페이스트를 만든다. 냄비에 설탕과 물을 넣고 젓지 않은 상태로 $118^{\circ} \mathrm{C}$ 까지 끓여 시럽 을 만든다. 볼(bowl)에 달걀흰자를 넣고 스탠드 믹서기 [KMC510, De'Longhi-Kenwood Appliance(Dongguan) Co., Ltd., Dongguan, China]로 1단에서 30초 동안 혼합한 후, 설탕을 넣고 3 단에서 2 분 동안 거품을 발생시켜 머랭을 만든다. 머랭이 $70 \%$ 정도 형성되면 앞서 만든 시럽을 천천 히 부으며, 이탈리안 머랭(80-90\%)를 완성시킨다. 이 이 탈리안 머랭을 아몬드 페이스트에 3번 나눠 섞고, 마카로 나주(파우더와 머랭을 섞어주어 머랭을 가라앉히고 반죽 을 부드럽게 하여 마카롱 식감을 만드는 작업)를 50 회 반

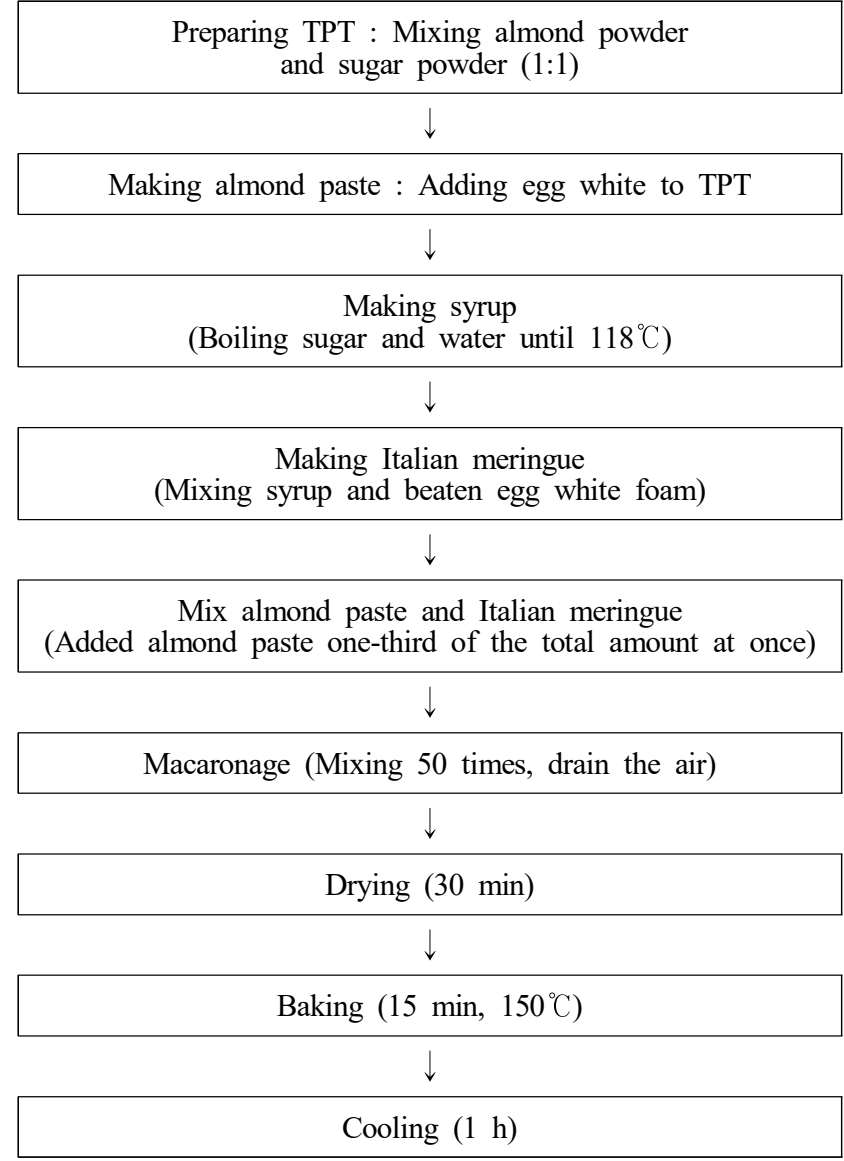

Fig. 1. Flowchart of macaron-making processes.

Table 1. Recipe of macaron

(unit: g)

\begin{tabular}{clc}
\hline & Sample & \\
\hline \multirow{3}{*}{ Almond paste } & Almond powder & 120 \\
& Sugar powder & 120 \\
& Egg white & 48 \\
\hline \multirow{2}{*}{ Syrup } & Sugar & 120 \\
& Water & 37 \\
\hline \multirow{2}{*}{ Meringue } & Sugar & 12 \\
& Egg white & 48 \\
\hline & Total & 505 \\
\hline
\end{tabular}

복하며, 거품을 꺼트려 덩어리가 없는 반죽을 완성한다. 반죽은 짤주머니에 담아 원형 깍지 806 번 $(\varnothing 1.3 \mathrm{~cm})$ 으로 $14.32 \mathrm{~g}$ 의 일정한 무게로 짠 후, 실온에서 30 분 건조한 후, $150^{\circ} \mathrm{C}$ 로 예열한 오븐(Briox Facile, Gierre, Milano, Italy) 에서 7 분간 굽다가 위치를 $180^{\circ}$ 돌려 8 분간 더 돌려주었고, 
완성된 코크는 실온에서 1시간 냉각한 후, 실험에 사용하 였다.

\section{저장 조건}

마카롱 코크는 서로 다른 3 가지의 저장 조건에서 3 주 동안 저장하며 품질 특성을 알아보았다. 저장 조건은 크게 냉장과 냉동으로 나누었는데, 냉장저장 시에는 마카롱 코 크만을 저장하였고, 냉동저장 시에는 마카롱 코크 2개 사 이에 버터크림으로 필링을 채워 저장하였다. 이는 냉장저 장 시에는 마카롱의 저장 특성이 좋지 않은 점을 반영하 여, 제조 직후의 마카롱 코크의 품질 특성을 가장 잘 유지 할 수 있는 저장 조건을 찾기 위해 냉장저장 조건에서는 필링을 제외한 코크만을 저장하였고, 냉동저장 조건에서 만 필링을 짜서 저장하였다. 냉장저장은 제조 직후부터 $4^{\circ} \mathrm{C}$ 에서 3 주 동안 저장하며 실험하였고, 냉동저장은 제조 직후부터 $-20^{\circ} \mathrm{C}$ 에서 3 주 동안 저장하며 실험 1 시간 전에 필링을 제거한 후 코크만을 각각 $25^{\circ} \mathrm{C}$ 의 실온과 $4^{\circ} \mathrm{C}$ 의 냉 장고에서 해동하였다. 모든 실험은 제조 직후 0 일부터 1 주, 2 주 및 3 주까지 저장하며 실험하였다.

\section{부피 측정}

마카롱 코크의 부피는 종자치환법(Pyler, 1979)을 사용 하여 측정하였다. 플라스틱 컵에 좁쌀만 가득 채운 다음, 마카롱 코크를 좁쌀이 든 컵에 넣었을 때 빠져나온 좁쌀의 양을 메스 실린더에 모아 부피를 측정하였다. 부피 측정은 오븐에서 구운 직후 1 시간 냉각 후에 측정하였으며, 3 주 저장 중에는 냉장저장한 코크와 냉동저장한 코크로 나누 어 5 회 이상 측정하였다.

\section{수분함량 측정}

마카롱 코크의 가운데 내부를 약 $1.0 \mathrm{~g}$ 을 취하여 적외선 수분측정기(Infrared Moisture Analyzer, FD-660, Kett Electric Laboratory, Tokyo, Japan)를 사용하여 측정하였다. 구운 직후 1 시간 냉각 후에 측정하였으며, 3 가지 저장 조건에서 보관하며 5 회 이상 측정하였다.

\section{조직감 측정}

마카롱 코크의 조직감을 알아보기 위하여 마카롱 코크 의 윗면을 Texture analyser(TA/XT2, Stable Micro System Ltd., Surrey, England)로 연속 2회 압착하였을 때 도출되는 힘-시간 곡선으로부터 경도(hardness), 씹힘성(chewiness), 검성(gumminess)를 10 회 이상 측정하였다. 기기의 probe 는 직경 $5 \mathrm{~mm}$ 의 SMS p/5를 사용하였고, 설정값은 pre-test, post-test 및 test speed는 $2.0 \mathrm{~mm} / \mathrm{s}$ 로 동일하게 설정하였고, $\operatorname{strain}$ (압축 시 변형률)은 $20 \%$ 로 하였다. 조직감 측정은 구운 직후 1 시간 냉각 후에 측정하였으며, 저장은 기간별
로 3 가지 조건상에서 측정하였다.

\section{관능검사}

마카롱 코크의 관능검사는 강도특성으로 평가하였다 (충남대학교 생명윤리위원회 생명윤리 면제심의 윤리면 제 승인번호: 201907-SB-105-01). 패널은 관능검사에 대한 교육과 예비실험을 통해 선발된 관능검사에 익숙한 충남 대학교 식품영양학과 대학생과 대학원생 8명을 선정하였 다. 시료는 동일한 크기로 잘라, 무작위 세 자릿수의 난수 표가 부착된 일회용 접시에 제시하였다. 시료 평가 전 따 뜻한 물로 입을 충분히 헹구고 1 분간 휴식을 취한 후 시료 를 평가하였다. 평가는 7점 척도법(1점: 매우 약함, 7점: 매우 강함)으로 하였고, 평가항목은 색상[코크의 색 (color)], 향[고소한 향(nutty flavor)], 맛[고소한 맛(nutty taste), 단맛(sweetness)], 조직감[촉촉한 정도(moisture), 경 도(hardness), 씹힘성(chewiness), 탄력성(springiness)], 전 반적인 수용도(overall acceptability)이다. 관능검사는 제조 직후에 실시하였으며, 저장 중에는 3 가지 저장 조건으로 나누어 실시하였다.

\section{통계처리}

본 연구의 모든 실험은 반복 측정한 값을 SPSS 24.0 (Statistical Package for Social Sciences, SPSS Inc., Chicago, IL, USA) software package를 통해 결과값으로 나타내었다. 기술통계를 통해 '평균표준편차'의 형태로 나타내었으 며, 분산분석(ANOVA)를 통해 유의성이 있을 경우 Duncan 의 다중범위검정(Duncan's multiple range test)을 실시하여 $5 \%$ 유의수준 $(\mathrm{p}<0.05)$ 에서 시료별, 저장 기간별 유의차를 검증하였다.

\section{결과 및 고찰}

\section{부피}

저장 온도를 달리하여 저장한 마카롱의 저장 기간별 부피 측정 결과는 Table 2 와 같다. 제조 직후 마카롱의 부피는 $25.33 \mathrm{~mL}$ 이고, 냉장저장의 경우 저장 1 주 차에는 $22.67 \mathrm{~mL}, 2$ 주 차에는 $22.67 \mathrm{~mL}, 3$ 주 차에는 $21.00 \mathrm{~mL}$ 로 제조 직후와 냉장저장 기간 간의 유의적인 차이가 나타났 다 $(\mathrm{p}<0.05)$. 냉동저장의 경우, 저장 1 주 차에는 $24.00 \mathrm{~mL}$, 2주 차에는 $21.33 \mathrm{~mL}, 3$ 주 차에는 $19.67 \mathrm{~mL}$ 로 저장 기간이 길어질수록 유의적으로 부피가 감소를 나타내었다 $(\mathrm{p}<0.05)$. 이러한 결과는 옥수수 전분 스폰지케이크(Kim과 Jang, 2005)의 결과와 동일한 경향을 나타내었다. 저장 3주 차에 는 제조 직후에 비해 냉장저장은 $4.33 \mathrm{~mL}$ 의 부피감소를, 냉동저장은 $5.66 \mathrm{~mL}$ 의 부피감소를 보이며, 냉장저장 시 부피의 감소가 더 작았다. 냉장저장은 저장 후반에 부피감 
Table 2. Volume of macaron during storage at $4^{\circ} \mathrm{C}$ and $-20^{\circ} \mathrm{C}$

\begin{tabular}{cccc}
\hline & $\begin{array}{c}\text { Storage time } \\
\text { (weeks) }\end{array}$ & $\mathrm{A}^{1)}$ & $\mathrm{B}$ \\
\hline & 0 & $25.33 \pm 1.53^{\mathrm{a} 2)}$ & $25.33 \pm 1.53^{\mathrm{a}}$ \\
$\begin{array}{c}\text { Volume } \\
(\mathrm{mL})\end{array}$ & 1 & $22.67 \pm 0.58^{\mathrm{b}}$ & $24.00 \pm 1.00^{\mathrm{a}}$ \\
& 2 & $22.67 \pm 0.58^{\mathrm{b}}$ & $21.33 \pm 0.58^{\mathrm{b}}$ \\
& 3 & $21.00 \pm 1.73^{\mathrm{b}}$ & $19.67 \pm 1.53^{\mathrm{b}}$ \\
\hline
\end{tabular}

${ }^{1)} \mathrm{A}$, refrigeration $\left(4^{\circ} \mathrm{C}\right)$ storage; $\mathrm{B}$, frozen storage and room temperature defrost $\left(-20^{\circ} \mathrm{C} \rightarrow 25^{\circ} \mathrm{C}\right)$.

${ }^{2)}$ Mean \pm SD $(n=3)$ within each column followed by the same letter are not significantly different $(\mathrm{p}<0.05)$.

소가 작았던 반면, 냉동저장은 저장 초반의 부피 감소가 작았다. 이와 같은 결과를 통해 저장 기간이 길어짐에 따 라 냉장저장이 코크의 부피 유지에 적절한 방법이라고 생각된다.

마카롱의 부피는 기포성을 가지는 계란 흰자로 제조한 머랭을 마카롱 반죽에 섞으면 코크를 굽는 동안 반죽 내 머랭이 부풀어 부피가 증가된다(Yoon과 Kim, 2009; Seo, 2019). 부피감은 머랭과 관련이 있기에 마카롱의 식감을 좌우하고(Seo, 2019), 머랭의 안정성 정도에 따라 최종 제 품의 부피나 질감 등에 영향을 미치기 때문에 $70 \%$ 정도의 단단한 머랭을 올리는 것이 중요하다(Seo, 2019).

\section{수분함량}

온도를 달리하여 저장한 마카롱의 저장 기간별 수분함 량 측정 결과는 Table 3 과 같다. 제조 직후 0 일 차에는 $11.59 \%$ 였지만, 저장 3 주 차에는 냉장저장이 $14.55 \%$, 냉동 저장 후 실온해동이 $14.77 \%$, 냉동저장 후 냉장해동이 $14.86 \%$ 로 저장 기간이 증가함에 따라 마카롱 코크의 내부 수분함량은 유의적으로 증가하였다 $(\mathrm{p}<0.05)$. 제조 직후 0 일 차와 비교해 저장 3 주 차에 수분함량 증가 정도는 냉동 저장 후 냉장해동한 것이 $3.27 \%$ 로 가장 높았다. 그다음은 냉동저장 후 실온해동한 것이 $3.18 \%$ 의 증가를, 냉장저장
이 $2.96 \%$ 의 증가를 보였다. Lee 등(2017)에서는 냉동에 의해 시료 표면의 수분증발현상이 느려져서 수분 손실이 감소함에 따라 냉동저장한 것이 냉장저장한 것보다 수분 함량이 높았다고 보고하였다. 이러한 보고로 보아, 본 연 구에서도 냉동저장한 것이 냉장저장한 것에 비해 수분함 량이 높게 나타난 것으로 판단된다. 또한, Kwon 등(2006) 에 따르면 냉동저장 후 실온해동한 것보다 냉장해동한 것이 드립의 용출이 적었다는 보고로 보아, 냉장해동을 한 것의 수분함량이 높게 나타난 것으로 판단된다.

아몬드 분말은 $100 \mathrm{~g}$ 기준 식이섬유가 $14.5 \mathrm{~g}$ 으로 풍부 한데(NAAS, 2016), 식이섬유는 수분 보유력과 밀접한 관 련이 있어서 Baek 등(2018)의 보고에서 아몬드 분말 첨가 량이 증가할수록 수분 보유력의 증가로 수분함량이 증가 하였다. 따라서 아몬드 분말이 주재료인 마카롱 또한 수분 보유력이 좋아 저장 기간이 증가함에 따라 코크 내부의 수 분함량이 저장 조건에 관계없이 유의적으로 증가하는 것으 로 사료된다 $(\mathrm{p}<0.05)$. 높은 수분함량은 시료의 촉촉함을 의미하므로, 저장 3 주 후의 마카롱 코크 내부 수분함량은 냉동저장 후 냉장해동의 수분함량이 가장 높기에, 이 조건 이 코크 내부가 가장 촉촉하게 유지된 것으로 판단된다.

\section{조직감}

식품의 조직감은 수분함량, 지방함량, 원료 등 다양한 요인에 의해 영향을 받는데, 조직감은 관능특성과도 밀접 한 관련이 있다(Song 등, 2000). 조직감은 식품을 구강 내 에서 씹을 때의 힘을 객관적인 수치로 나타내어주는 것으 로 경도, 검성, 씹힘성을 측정하였다. 경도란 설정한 변형 률에 도달하는데 요구되는 힘으로, 힘-시간 곡선에서는 첫 번째 그래프상의 최대 peak의 크기를 나타낸다. 검성은 반고체 상태의 시료의 삼킬 수 있을 정도로 만드는 성질이 고, 씹힘성은 고체 상태의 시료를 삼킬 수 있을 정도로 만드는 성질이며(Kim 등, 2006), 특히 쫀득한 특성을 가지 는 마카롱의 조직감에서 검성, 씹힘성은 특히 중요하다.

저장 온도를 달리하여 저장한 마카롱의 저장 기간별 조직감 측정 결과는 Table 4와 같다. 경도는 제조 직후

Table 3. Moisture content (\%) of macaron during storage at different conditions

\begin{tabular}{ccccc}
\hline & Storage time (weeks) & $\mathrm{A}^{1)}$ & $\mathrm{B}$ & $\mathrm{C}$ \\
\hline & 0 & $11.59 \pm 0.54^{\mathrm{c} 2}$ & $11.59 \pm 0.54^{\mathrm{d}}$ & $11.59 \pm 0.54^{\mathrm{d}}$ \\
Moisture content & 1 & $11.35 \pm 0.21^{\mathrm{c}}$ & $12.64 \pm 0.22^{\mathrm{c}}$ & $12.48 \pm 0.24^{\mathrm{c}}$ \\
$(\%)$ & 2 & $13.77 \pm 0.13^{\mathrm{b}}$ & $13.48 \pm 0.42^{\mathrm{b}}$ & $13.48 \pm 0.32^{\mathrm{b}}$ \\
& 3 & $14.55 \pm 0.42^{\mathrm{a}}$ & $14.77 \pm 0.21^{\mathrm{a}}$ & $14.86 \pm 0.10^{\mathrm{a}}$ \\
\hline
\end{tabular}

${ }^{1)} \mathrm{A}$, refrigeration $\left(4^{\circ} \mathrm{C}\right)$ storage; $\mathrm{B}$, frozen storage and room temperature defrost $\left(-20^{\circ} \mathrm{C} \rightarrow 25^{\circ} \mathrm{C}\right)$; $\mathrm{C}$, frozen storage and refrigeration defrost $\left(-20^{\circ} \mathrm{C}\right.$ $\rightarrow 4^{\circ} \mathrm{C}$ ).

${ }^{2)}$ Mean \pm SD ( $\left.n=3\right)$ within each column followed by the same letter are not significantly different $(\mathrm{p}<0.05)$. 
Table 4. Textual properties of macaron during storage at different conditions

\begin{tabular}{|c|c|c|c|c|}
\hline & Storage time (weeks) & $\mathrm{A}^{1)}$ & $\mathrm{B}$ & $\mathrm{C}$ \\
\hline \multirow{4}{*}{ Hardness (g) } & 0 & $914.43 \pm 50.89^{\mathrm{b} 2)}$ & $914.43 \pm 50.89^{\mathrm{b}}$ & $914.43 \pm 50.89^{\mathrm{a}}$ \\
\hline & 1 & $812.55 \pm 201.07^{\mathrm{b}}$ & $1,199.90 \pm 120.97^{\mathrm{a}}$ & $995.20 \pm 105.67^{\mathrm{a}}$ \\
\hline & 2 & $1,320.28 \pm 124.79^{\mathrm{a}}$ & $613.12 \pm 43.91^{\mathrm{c}}$ & $596.96 \pm 52.67^{\mathrm{b}}$ \\
\hline & 3 & $1,481.00 \pm 275.77^{\mathrm{a}}$ & $460.89 \pm 63.78^{d}$ & $529.98 \pm 65.37^{b}$ \\
\hline \multirow{4}{*}{ Gumminess } & 0 & $114.89 \pm 8.71^{\mathrm{NS} 33}$ & $114.89 \pm 8.71^{\mathrm{a}}$ & $114.89 \pm 8.71^{\mathrm{ab}}$ \\
\hline & 1 & $120.59 \pm 46.55$ & $71.36 \pm 16.52^{\mathrm{b}}$ & $86.24 \pm 43.53^{\mathrm{b}}$ \\
\hline & 2 & $135.39 \pm 87.68$ & $113.64 \pm 24.50^{\mathrm{a}}$ & $155.12 \pm 62.28^{\mathrm{a}}$ \\
\hline & 3 & $163.18 \pm 52.83$ & $108.23 \pm 23.05^{\mathrm{a}}$ & $104.63 \pm 31.82^{\mathrm{ab}}$ \\
\hline \multirow{4}{*}{ Chewiness } & 0 & $73.27 \pm 19.90^{\mathrm{NS}}$ & $73.27 \pm 19.90^{\mathrm{a}}$ & $73.27 \pm 19.90^{\mathrm{ab}}$ \\
\hline & 1 & $75.02 \pm 35.06$ & $31.55 \pm 10.52^{\mathrm{b}}$ & $42.14 \pm 28.09^{\mathrm{b}}$ \\
\hline & 2 & $103.52 \pm 63.42$ & $57.19 \pm 24.96^{\mathrm{ab}}$ & $96.82 \pm 52.82^{\mathrm{a}}$ \\
\hline & 3 & $94.58 \pm 30.06$ & $62.47 \pm 22.23^{\mathrm{a}}$ & $58.10 \pm 29.90^{\mathrm{ab}}$ \\
\hline
\end{tabular}

${ }^{1)} \mathrm{A}$, refrigeration $\left(4^{\circ} \mathrm{C}\right)$ storage; $\mathrm{B}$, frozen storage and room temperature defrost $\left(-20^{\circ} \mathrm{C} \rightarrow 25^{\circ} \mathrm{C}\right)$; $\mathrm{C}$, frozen storage and refrigeration defrost $\left(-20^{\circ} \mathrm{C}\right.$ $\rightarrow 4^{\circ} \mathrm{C}$ ).

${ }^{2)} \mathrm{Mean} \pm \mathrm{SD}(\mathrm{n}=3)$ within each column followed by the same letter are not significantly different $(\mathrm{p}<0.05)$.

${ }^{3} \mathrm{NS}$, not significant.

0일 차에 $914.43 \mathrm{~g}$ 으로 저장 1주 차까지는 대개 유의적인 차이를 보이지 않았지만, 저장 2주 차부터는 유의적인 차 이를 보이며, 저장 3주 차에 냉장저장은 $1,481.00 \mathrm{~g}$ 으로 0 일 차에 비해 유의적으로 증가하였고 $(\mathrm{p}<0.05)$, 냉동저장 후 실온해동과 냉장해동은 각각 $460.89 \mathrm{~g}, 529.98 \mathrm{~g}$ 으로 0 일 차에 비해 유의적으로 감소하였다 $(\mathrm{p}<0.05)$. 냉장저장 과 냉동저장이 다른 경향을 보인 이유는 냉장저장의 마카 롱 코크는 필링 없이 저장되어 코크의 겉면은 냉장저장 시 수분이 손실되어 점차 단단해진 것으로 사료되고, 냉동 저장 시에는 마카롱 코크 사이에 필링을 채웠는데, 필링의 수분이 마카롱 코크로 이동하여 코크 겉면의 수분이 점차 증가하고, 냉동저장 시에는 수분 증발이 느려짐(Lee 등, 2017)에 따른 경도의 감소로 사료된다. 검성은 제조 직후 0 일 차에 114.89 였고, 저장 3 주 차에는 냉장저장은 163.18 로 저장 기간의 증가에 따라 값이 증가하였고, 냉동저장 후 실온해동과 냉장해동은 각각 $108.23,104.63$ 으로 최종 적으로 값이 감소하였다 $(\mathrm{p}>0.05)$. 그리고 마카롱의 중요한 특성인 씹힘성은 제조 직후 0 일 차에 73.27 이었고, 저장 3 주 차에는 냉장저장은 94.58로 값이 증가한 반면, 냉동저 장 후 실온해동과 냉장해동은 각각 $62.47,58.10$ 으로 값이 감소하였다 $(\mathrm{p}>0.05)$. 조직감 특성 중 검성과 씹힘성은 실 온해동과 냉장해동 중 냉장해동이 더 낮은데, 이는 냉장해 동이 수분 증발이 더 적음에 따라 조직감 측정값이 낮은 것이라고 사료된다(Kwon 등, 2006). 이로써 검성과 씹힘
성은 경도와 비슷한 경향을 가진다.

따라서 마카롱을 장기간 저장할 경우, 필링 없이 냉장 보관할 경우에는 겉면이 점차 단단해지지만, 필링을 채워 냉동 보관하면 코크의 겉면이 부드러워지므로 필링을 채 운 채로 저장하는 것이 좋으며, 냉동저장 후 냉장해동하는 것이 더 촉촉하고 부드러울 것으로 사료된다.

\section{관능검사}

식품과 관련된 감각은 외형, 냄새, 맛, 조직감 등으로 구분되고, 이는 눈, 코, 입, 피부 등으로 인지되므로 관능검 사 항목은 이와 관련이 있다. 외형적 특성은 시각에 의해 처음으로 인지하게 되는 시료 평가에 큰 영향을 주는 항목 으로 본 연구에서는 외형적 특성 중 색에 관하여 평가하였 다. 좋은 냄새는 식품을 섭취하는 사람으로 하여금 즐거움 을 주는 특성으로, 본 연구에서는 고소한 향에 대하여 평 가하였다. 맛 또한 시료에 큰 영향을 주는 요인으로 고소 한 맛, 단맛에 대하여 평가하였고, 조직감은 복합적인 특 성으로 촉촉한 정도, 경도, 씹힘성, 탄력성에 대하여 평가 하였다. 전반적인 수용도는 앞선 관능적 특성들에 대한 전체적인 평가이다.

저장 온도를 달리하여 저장한 마카롱의 저장 기간별 관능검사 결과는 Table 5 와 같다. 색은 저장 3 주 후에 냉장 저장이 1.9점, 냉동저장 후 실온해동이 2.8점, 냉동저장 후 냉장해동은 2.0점으로 냉동저장 후 실온해동이 가장 
Table 5. Sensory evaluation test ${ }^{1)}$ of macaron during storage at different conditions

\begin{tabular}{|c|c|c|c|c|c|}
\hline & & Storage time (week) & $\mathrm{A}^{2)}$ & $\mathrm{B}$ & $\mathrm{C}$ \\
\hline \multirow{4}{*}{\multicolumn{2}{|c|}{ Color }} & 0 & $2.5 \pm 1.3^{3) \mathrm{NS} 4)}$ & $2.5 \pm 1.3^{\mathrm{NS}}$ & $2.5 \pm 1.3^{\mathrm{NS}}$ \\
\hline & & 1 & $3.0 \pm 0.9$ & $3.1 \pm 1.4^{3)}$ & $2.5 \pm 0.9$ \\
\hline & & 2 & $2.9 \pm 2.1$ & $3.0 \pm 1.9$ & $2.3 \pm 1.2$ \\
\hline & & 3 & $1.9 \pm 0.6$ & $2.8 \pm 1.0$ & $2.0 \pm 0.8$ \\
\hline \multirow{4}{*}{\multicolumn{2}{|c|}{ Nutty flavor }} & 0 & $1.8 \pm 0.5^{\mathrm{NS}}$ & $1.8 \pm 0.5^{\mathrm{NS}}$ & $1.8 \pm 0.5^{\mathrm{b}}$ \\
\hline & & 1 & $1.8 \pm 0.5$ & $1.9 \pm 0.6$ & $2.9 \pm 1.1^{\mathrm{a}}$ \\
\hline & & 2 & $2.1 \pm 1.0$ & $2.9 \pm 1.5$ & $2.5 \pm 1.2^{\mathrm{ab}}$ \\
\hline & & 3 & $1.9 \pm 0.8$ & $2.0 \pm 1.3$ & $1.6 \pm 0.7^{b}$ \\
\hline \multirow{8}{*}{ Taste } & \multirow{4}{*}{ Nutty } & 0 & $2.3 \pm 0.7^{\mathrm{NS}}$ & $2.3 \pm 0.7^{\mathrm{NS}}$ & $2.3 \pm 0.7^{\mathrm{NS}}$ \\
\hline & & 1 & $2.0 \pm 0.8$ & $2.0 \pm 0.5$ & $2.1 \pm 1.0$ \\
\hline & & 2 & $2.1 \pm 1.0$ & $2.4 \pm 1.5$ & $2.3 \pm 1.2$ \\
\hline & & 3 & $2.0 \pm 0.8$ & $2.9 \pm 1.1$ & $2.3 \pm 0.9$ \\
\hline & \multirow{4}{*}{ Sweetness } & 0 & $5.8 \pm 1.3^{\mathrm{a}}$ & $5.8 \pm 1.3^{\mathrm{a}}$ & $5.8 \pm 1.3^{\mathrm{NS}}$ \\
\hline & & 1 & $5.6 \pm 1.1^{\mathrm{a}}$ & $5.1 \pm 1.5^{\mathrm{ab}}$ & $4.6 \pm 1.5$ \\
\hline & & 2 & $4.0 \pm 2.1^{\mathrm{b}}$ & $3.8 \pm 2.4^{\mathrm{b}}$ & $4.0 \pm 2.4$ \\
\hline & & 3 & $4.4 \pm 0.9^{\mathrm{ab}}$ & $3.9 \pm 0.8^{\mathrm{b}}$ & $4.4 \pm 0.7$ \\
\hline \multirow{16}{*}{ Texture } & \multirow{4}{*}{ Moisture } & 0 & $4.5 \pm 2.4^{\mathrm{NS}}$ & $4.5 \pm 2.4^{\mathrm{NS}}$ & $4.5 \pm 2.4^{\mathrm{NS}}$ \\
\hline & & 1 & $2.8 \pm 1.6$ & $5.0 \pm 2.4$ & $3.6 \pm 2.1$ \\
\hline & & 2 & $3.6 \pm 1.8$ & $4.4 \pm 2.3$ & $4.4 \pm 2.4$ \\
\hline & & 3 & $3.0 \pm 1.6$ & $3.9 \pm 1.6$ & $4.3 \pm 1.4$ \\
\hline & \multirow{4}{*}{ Hardness } & 0 & $2.8 \pm 1.5^{b}$ & $2.8 \pm 1.5^{\mathrm{NS}}$ & $2.8 \pm 1.5^{\mathrm{NS}}$ \\
\hline & & 1 & $5.0 \pm 1.7^{\mathrm{a}}$ & $2.5 \pm 1.3$ & $2.9 \pm 1.1$ \\
\hline & & 2 & $4.0 \pm 2.0^{\mathrm{ab}}$ & $3.6 \pm 2.0$ & $2.4 \pm 1.1$ \\
\hline & & 3 & $4.0 \pm 1.4^{\mathrm{ab}}$ & $3.4 \pm 1.1$ & $3.4 \pm 2.0$ \\
\hline & \multirow{4}{*}{ Chewiness } & 0 & $2.4 \pm 1.2^{\mathrm{c}}$ & $2.4 \pm 1.2^{\mathrm{NS}}$ & $2.4 \pm 1.2^{\mathrm{NS}}$ \\
\hline & & 1 & $4.5 \pm 1.7^{\mathrm{a}}$ & $2.6 \pm 1.5$ & $3.1 \pm 1.4$ \\
\hline & & 2 & $2.6 \pm 1.6^{\mathrm{bc}}$ & $3.5 \pm 2.3$ & $2.5 \pm 0.9$ \\
\hline & & 3 & $4.0 \pm 1.4^{\mathrm{ab}}$ & $3.6 \pm 0.9$ & $3.1 \pm 0.6$ \\
\hline & \multirow{4}{*}{ Springiness } & 0 & $5.0 \pm 1.9^{\mathrm{a}}$ & $5.0 \pm 1.9^{\mathrm{NS}}$ & $5.0 \pm 1.9^{\mathrm{a}}$ \\
\hline & & 1 & $2.4 \pm 1.3^{\mathrm{b}}$ & $2.8 \pm 1.8$ & $2.8 \pm 1.6^{\mathrm{b}}$ \\
\hline & & 2 & $2.5 \pm 1.3^{\mathrm{b}}$ & $3.0 \pm 1.7$ & $2.9 \pm 1.6^{\mathrm{b}}$ \\
\hline & & 3 & $2.1 \pm 0.6^{\mathrm{b}}$ & $2.9 \pm 1.2$ & $3.0 \pm 1.3^{\mathrm{b}}$ \\
\hline \multirow{4}{*}{\multicolumn{2}{|c|}{ Overall acceptability }} & 0 & $5.6 \pm 0.9^{\mathrm{a}}$ & $5.6 \pm 0.9^{\mathrm{a}}$ & $5.6 \pm 0.9^{\mathrm{a}}$ \\
\hline & & 1 & $5.0 \pm 1.2^{\mathrm{ab}}$ & $4.4 \pm 1.7^{\mathrm{b}}$ & $4.5 \pm 1.4^{\mathrm{ab}}$ \\
\hline & & 2 & $4.1 \pm 0.6^{\mathrm{bc}}$ & $4.6 \pm 0.9^{\mathrm{ab}}$ & $4.3 \pm 1.6^{\mathrm{b}}$ \\
\hline & & 3 & $4.0 \pm 0.8^{\mathrm{c}}$ & $4.6 \pm 0.7^{\mathrm{ab}}$ & $4.3 \pm 0.7^{\mathrm{b}}$ \\
\hline
\end{tabular}

${ }^{1)} 7$ point Likert scale: 1-extremely low, 7-extremely high.

${ }^{2)} \mathrm{A}$, refrigeration $\left(4^{\circ} \mathrm{C}\right)$ storage macaron; $\mathrm{B}$, frozen storage and room temperature defrost $\left(-20^{\circ} \mathrm{C} \rightarrow 25^{\circ} \mathrm{C}\right)$; $\mathrm{C}$, frozen storage and refrigeration defrost $\left(-20^{\circ} \mathrm{C} \rightarrow 4^{\circ} \mathrm{C}\right)$.

${ }^{3)}$ Mean \pm SD $(n=3)$ within each column followed by the same letter are not significantly different $(p<0.05)$.

${ }^{4)} \mathrm{NS}$, not significant. 
점수가 높았는데, 실온해동한 마카롱 코크가 탈색이 적게 되고, 색 유지가 잘 되었기에 높은 점수를 받은 것으로 판단된다. 고소한 향은 저장 3 주 차에 실온해동 마카롱이 2.0점으로 점수가 가장 높았다. 이 또한 3가지 저장 조건 중 향의 보존을 가장 잘해서 나온 결과라고 판단된다. 고 소한 맛은 저장 3주 차에 실온해동이 2.9점으로 가장 점수 가 높게 나왔다. 반면, 단맛은 냉장저장과 냉동저장 후 냉 장해동이 4.4점으로 가장 높았다. 조직감은 촉촉한 정도가 0 일차에는 4.5 점이고, 저장 3 주 차에는 냉장저장, 냉동저 장 후 실온해동, 냉동저장 후 냉장해동이 각각 3.0점, 3.9 점, 4.3점으로, 이는 저장 3 주 차 시료의 수분함량 결과와 일치하는데, 냉장해동한 코크의 내부 수분함량이 가장 많 아서 촉촉한 것으로 사료된다. 경도는 0 일 차에는 2.8 점이 고, 저장 3 주 차에는 냉장저장, 냉동저장 후 실온해동, 냉 동저장 후 냉장해동이 각각 4.0점, 3.4점, 3.4점인데, 이는 조직감 측정(Table 4)에서 냉장저장이 가장 경도가 높고, 냉동저장 후 냉장해동, 실온해동 순이었던 것과 비슷한 결과를 보인다고 생각된다. 씹힘성은 0 일 차에는 2.4점이 고, 저장 3 주 차에는 냉장저장, 냉동저장 후 실온해동, 냉 동저장 후 냉장해동이 각각 4.0점, 3.6점, 3.1점인데, 이는 조직감 측정(Table 4)의 씹힘성 측정 결과와 경향이 일치 한다. 탄력성은 0 일차에는 5.0 점이고, 저장 3 주 차에는 냉 장저장, 냉동저장 후 실온해동, 냉동저장 후 냉장해동이 각각 2.1점, 2.9점, 3.0점으로 냉동저장 후 냉장해동이 가장 탄력성이 높은 것으로 나타났다. 탄력성은 쫀득함과 관련 이 있을 것으로 생각되는데, 이러한 결과로 보아 냉동저장 후 냉장해동의 코크가 가장 쫀득할 것으로 사료된다. 전반 적인 수용도는 0 일차에는 5.6점이고, 저장 3 주 차에는 냉 장저장, 냉동저장 후 실온해동, 냉동저장 후 냉장해동이 각각 4.0점, 4.6점, 4.3점으로 냉동저장 후 실온해동의 점수 가 가장 높게 나타났다. 이러한 이유는 시료 평가에 가장 큰 영향을 주는 항목인 색이 가장 잘 유지된 것 때문으로 생각되고, 고소한 향 및 맛의 점수가 가장 높았고, 탄력성 도 비교적 높았기에 여러 관능 항목들이 영향을 미쳐 나온 결과라고 사료된다.

\section{요 약}

본 연구에서는 최근 우리나라의 디저트 시장에서 큰 사랑을 받고 있는 쿠키류 중 하나인 마카롱을 서로 다른 저장 조건에서 저장하였을 때 품질 특성의 변화를 알아보 았다. 저장 조건은 냉장저장, 냉동저장 후 실온해동, 냉동 저장 후 냉장해동으로 총 3 가지이고, 냉동저장 중의 코크 는 코크 2개 사이에 필링을 채운 후 저장하다가 해동 전에 제거하였다. 실험 항목은 부피, 수분함량, 조직감, 관능검 사이다. 부피는 마카롱 코크 전체를 냉장과 냉동 조건 2가
지에서 측정하였는데, 저장 초기에는 냉동 조건에서의 부 피 변화가 적었지만, 저장 기간이 지날수록 냉장 조건에서 의 부피 변화가 거의 나타나지 않았다. 수분함량은 마카롱 코크의 가운데 내부를 측정하였는데, 3 가지 저장 조건에 서 저장하였을 때 0 일 차에 비해 모두 값이 증가하였다. 값은 냉동저장 후 냉장저장, 냉동저장 후 실온해동, 냉장 해동 순으로 높았는데, 이 결과를 통해 냉동저장 후 냉장 저장한 것의 코크 내부의 촉촉함이 가장 높을 것으로 생각 된다. 조직감은 마카롱 코크 전체의 경도, 검성, 씹힘성을 측정하였는데, 0 일 차에 비해 저장 3 주 차에서 냉장저장의 값은 모두 증가한 반면, 냉동저장 한 시료 2개는 모두 값이 감소하였고, 특히 마카롱과 관련 있는 씹힘성과 검성은 냉동저장 후 냉장저장이 가장 낮은 값을 보였다. 0 일차에 비해 저장 기간이 지난 후 값이 감소하거나 증가하는 차이 는 필링의 유무와 관련이 있고, 냉동저장 시료 간의 차이 는 해동 방법에 따른 결과로 사료된다. 따라서 장기간 저 장 시에도 필링을 채워 냉동저장하는 것이 마카롱 코크의 부드러움을 유지시켜 줄 것으로 사료된다. 관능검사 중 전체적인 수용도는 냉동저장 후 실온해동에서 가장 높았 는데, 이는 관능검사 큰 영향을 미치는 색과 고소한 향과 맛, 탄력성의 점수가 높음에 따른 결과라고 사료된다. 따 라서 마카롱 코크를 장기간 저장하기에 적절한 방법으로 는 관능검사에서 전반적인 수용도 점수가 가장 높았던 냉동저장 후 실온해동이라고 생각된다.

\section{Conflict of interests}

The authors declare no potential conflict of interest.

\section{ORCID}

Young Mi Park https://orcid.org/0000-0002-4321-4434 Mee Ree Kim https://orcid.org/0000-0003-3813-1447

\section{References}

Baek SY, Choi CU, Kim MR. Storage characteristics and retrogradation properties of Sulgidduk added with almond powder. J Korean Soc Food Sci Nutr, 47, 638-648 (2018)

Bing DJ, Chun SS. Quality characteristics and antioxidant properties of rice chiffon cakes with wild grape powder. J Korean Soc Food Sci Nutr, 44, 118-127 (2015)

Kim AJ, Yuh CS, Bang IS. A qualitative investigation of Dongchunghacho jelly with assorted increments of Paecilomyces japonica powder. Korean J Food Nutr, 20, 40-46 (2007) 
Kim KJ. Quality characteristics and antioxidant activities of macaron with cabbage powder. Food Eng Prog, 21, 367-374 (2017)

Kim MJ, Jang MS. Quality characteristics of sponge cakes with addition of corn starch. J Korean Soc Food Sci Nutr, 34, 1427-1433 (2005)

Kim MR, Imm JY. Convenient method for the determination of foaming properties of egg white and its verification. Korean J Food Sci Technol, 36, 728-732 (2004)

Kim MZ, Sim KH. Quality characteristics and antioxidative activities of macaron with the addition of egg white powder. Korean J Food Nutr, 30, 269-281 (2017)

Kim SY, Han GD, Jung IC, Kim KJ. Quality characteristics and antioxidant activities of macaron with Opuntia ficusindica var. saboten powder. J East Asian Soc Diet Life, 27, 332-340 (2017)

Korea Agro-Fisheries and Food Trade Corporation (aT). The status of processed foods market: confectionary market. Final Report of aT, aT 11-1543000-001456-01, https:// www.atfis.or.kr/fip/article/M000010401/view.do?artic leId=2995 (2016)

Korean Bakery Association. Meringue. Monthly Bakery, 420, 163-165 (2013)

Kwon DJ, Kim MH, Lee NH, Kwon OJ, Son DH, Choi UK. Quality characteristics of frozen maesil (Prunus mume Sieb. et Zucc.) according to thawing method. Korean J Food Culture, 21, 426-432 (2006)

Lee JH, Lee JK, Jeong JT, Choi JS, Choi YI. Quality properties of frozen and cold pork cutlet and hamburger steak. Bull Anim Biotechnol, 9, $51-57$ (2017)

Lee KS, Kim SH. Analysis of characteristics of the white bread with mixed vegetable powder. Korean J Hospitality Tourism, 16, 169-184 (2007)
Lee MW, Choi SY, Yoo KM, Lim SY, Jung WS. Development of value-added macarone with Perilla frutescens powders and their physiological characteristics. Korean J Food Nutr, 28, 66-72 (2015)

Lovejoy JC, Most MM, Lefevre M, Greenway FL, Rood JC. Effects of diets enriched in almonds on insulin action and serum lipids in adults with normal glucose tolerance in type 2 diabetes. Am J Clin Nutr, 76, 1000-1006 (2002)

National Institute of Agricultural Sciences (NAAS). 9th ed, Korean Food Composition Table, Jeonju, Korea (2016)

Park OJ, Park MH, Lee SH, Lee SM. Characteristics of macaroons prepared with natural materials and artificial food colorant. Korean J Food Nutr, 31, 631-639 (2018)

Peom JW. Characteristics and manufacture of macaroon cookie prepared with black ginseng powder. MS Thesis, Hansung University, Korea, p 1-2 (2013)

Pyler EJ. Physical and chemical test methods. In: Baking Science and Technology, Pyler EJ, Gorton LA (Editors), Sosland Publishing Co, Manhattan, KS, USA, p 891 (1979)

Seo GY. Brechel Macaron One Book. Book Ownership Publishing Co, Seoul, Korea, p 33, 36 (2019)

Shin SK, Lee SW, Lee SJ, Joo NY, Choi NS. Food Processing and Preservation. PowerBook Publishing Co, Goyang, Korea, p 240-241 (2010)

Song HI, Moon GI, Moon YH, Jung IC. Quality and storage stability of hamburger during low temperature storage. Korean J Food Sci Ani Resour, 20, $72-78$ (2000)

Won KR. Anticipated Questions of Bakery Technician. Hyun Neung Publishing Co, Seoul, Korea, p 31 (2011)

Yoon KH, Kim MK. Quality characteristics and storage properties of chiffon-cake containing added bamboo leaf powder. Korean J Food Culture, 24, 552-560 (2009) 